\title{
METODE ISTINBAT HUKUM ZAKAT PROFESI PERSPEKTIF YUSUF ALQARDAWI DAN IMPLIKASINYA TERHADAP PENGEMBANGAN OBJEK ZAKAT DI INDONESIA
}

\author{
Muhammad Aziz ${ }^{1}$ L Sholikah ${ }^{2}$ \\ Sekolah Tinggi Agama Islam (STAI) al-Hikmah Tuban ${ }^{1}$ \\ Sekolah Tinggi Ilmu Tarbiyah Makhdum Ibrahim (STITMA) Tuban ${ }^{2}$ \\ Email: azizindil@gmail.com
}

\begin{abstract}
The practice of profession charity rose in Indonesia after the presence of Yusuf al Qardlawi's book entitled figh al zakah, which discusses the compulsory zakah of profession for Muslims. This study explores how the istinbath method of profession zakah law is based on Qardawi's perspective and implications of the output of his ideas toward the development of zakat in Indonesia. This study concluded that Qardawi's method in istinbath to determine the basis of the compulsory profession zakah for every Muslim is qiyas method. Provided that maqis 'alaih is as charity of gold and silver; its 'illat is growing (al nama'); the legal obligation for the profession zakat is worth with gold-silver or similar to the compulsory gold-silver charity; and the far'u of his profession zakah. While the implications of istinbath method is that the object of zakat in Indonesia, which was originally based solely on the zakah object based on conventional classical fiqh (gold-silver zakah, agricultural-crops, animals etc.), leads the object charity in the field of occupations and professions developed in modern era, such as commissioners, advocates, public accountants etc.
\end{abstract}

Praktek zakat profesi mengemuka di Indonesia pasca munculnya buku Yusufal Qardawi yang berjudul figh al zakah yang membahas wajibnya zakat profesi bagi umat Islam. Penelitian ini mengungkap bagaimana metode istinbath hukum zakat profesi perspektif pemikiran Yusuf al Qardawi dan implikasi output dari pemikirannya terhadap pengembangan objek zakat di Indonesia Penelitian ini

Ulul Albab Volume 16, No.1 Tahun 2015 
berkesimpulan bahwa metode yang digunakan Yusuf al Qardawi dalam beristinbath untuk menentukan dasar wajibnya zakat profesi bagi setiap umat Islam adalah metode qiyas. Digunakan ketentuan maqis 'alaih-nya yaitu zakat emas dan perak; 'illat-nya adalah berkembang (al nama'); hukum adanya kewajiban zakat bagi profesi yang senilai dengan emas-perak atau seperti diwajibkannya zakat emas-perak; dan far'u-nya zakat profesi. Sedangkan implikasi dari hasil metode istinbath adalah bahwa objek zakat di Indonesia yang semula hanya bertumpu pada objek zakat berdasarkan figh klasik konvensional (zakat emasperak, pertanian-tanaman, hewan dll), menuju ke arah objek zakat pada bidang pekerjaan serta profesi yang berkembang di era modern, seperti komisaris perusahaan, advokat, akuntan publik dan lain-lain.

Keywords: profession zakah, istinbath

\section{Pendahuluan}

Salah satu objek zakat yang sampai hari ini masih diperdebatkan ahli hukum Islam, adalah zakat profesi (Faridah, 2011: 152). Ada banyak hal yang menyebabkan zakat profesi secara hukum dianggap tanpa dasar pijakan yang kuat dalam tradisi hukum Islam, diantaranya; keberadaan zakat profesi belum pernah dipraktekkan oleh Nabi SAW pada zaman dia masih hidup (al Qardawi, 1973: 167), hal ini membuat eksistensi zakat profesi ini menjadi hal yang dianggap ahistoris dalam syariat Islam. Padahal, pengamalan suatu bentuk aktifitas ibadah/muamalah oleh Nabi SAW semasa dia masih hidup, akan membuat bentuk aktifitas ibadah/muamalah tersebut memiliki legalitas dan landasan yang kuat, karena pengamalan Nabi adalah bagian dari penafsiran dia terhadap ajaran prinsipil yang bersumber dari al Quran.

Disamping itu, legalitas dan landasan akan cukup kuat, apabila ada ulama' (khususnya klasik) yang melegitimasi hal tersebut, padahal mengenai harta kekayaan yang wajib dizakati ulama klasik sepakat ada empat macam, yaitu: emas perak, binatang ternak, tanaman/buah-buahan dan harta perniagaan (Ismail, 1986: 176), memang redaksi al Quran yang berbicara tentang zakat, baik itu menyangkut prinsip tuntutan dan anjuran untuk berzakat, prinsip pengelolaan zakat, prinsip hikmah dan manfaat zakat, banyak telah menyebutkannya, akan tetapi keberadaan ayat-ayat tersebut rata-rata hanya berbicara pada ranah yang umum/global, kecuali prinsip al Quran tentang orang-orang yang menjadi penerima zakat (mustahiq zakah), hal itu dibuktikan dengan QS al Taubah ayat 60:

Artinya: Sesungguhnya zakat-zakat itu, hanyalah untuk orang-orang fakir, orangorang miskin, pengurus-pengurus zakat, Para mualaf yang dibujuk hatinya, untuk 
(memerdekakan) budak, orang-orang yang berhutang, untuk jalan Allah dan untuk mereka yuang sedang dalam perjalanan, sebagai suatu ketetapan yang diwajibkan Allah, dan Allah Maha mengetahui lagi Maha Bijaksana.

Maka dari itu dalam kajian tentang zakat profesi, ada sebagian orang yang tidak menerima sebagai objek zakat. Organisasi massa Islam Muhammadiyah, pada mulanya belum menerima/sepakat zakat profesi sebagai objek zakat, hasil Muktamar Tarjih Muhammadiyah XXI yang diselenggarakan di Kota Malang tanggal 12-16 Februari 1989, yang membahas tentang zakat profesi, akan tetapi masalah tersebut belum bisa diselesaikan, karena belum adanya kesepakatan final. Kemudian, baru pada Munas Tarjih Muhammadiyah XXV di Jakarta tanggal 5-7 Juli 2000, berhasil menetapkan, bahwa zakat profesi wajib (Muhammad, 2002: 48). Ini menunjukkan ada dinamika pemikiran hukum yang berkembang, tentunya menggunakan metodologi ijitihad dan istinbath yang cukup kuat dalam menetapkan hukum baru.

Selain itu juga menurut Sahal Mahfudh, sebenarnya tidak ada ketentuan syari'at tentang zakat profesi. Jika memang ada, ya diada-adakan (Kelib, 1996: 118). Sehubungan dengan itu, dia menyatakan bahwa gaji dan penghasilan profesi tidak wajib dizakati. Sebab kedua hal tersebut tidak memenuhi syarat haul dan nishab. Gaji kalau ditotal setahun mungkin memenuhi nishab, padahal gaji diberikan setiap bulan. Oleh karenanya gaji setahun memenuhi nishab itu hanya memenuhi syarat hak, tidak memenuhi syarat milik. Sementara itu, benda yang wajib dizakati harus mememiliki syarat milik. Hal ini didasarkan pada pendapat al Syafi'i (Mahfudh, 1994: 147). Lain dari itu, al Qardawi dalam figh al zakah-nya memberikan porsi khusus, atau paling tidak memasukkan item zakat profesi dalam objek harta yang harus dizakati oleh setiap muslim yang memenuhi syarat dan rukunnya (al Qardawi, 1973: 489).

Berdasarkan persoalan yang disebutkan di atas, ternyata masih banyak perbedaan pendapat antara para ulama, ada yang mewajibkan dan ada juga yang tidak mewajibkan. Di Indonesia sendiri MUI masih berbeda pendapat tentang wajib atau tidaknya zakat profesi, atau paling tidak belum menyepakati untuk mengeluarkan fatwa tentang hal ini (Muhammad, 2002: 03). Itulah sebabnya penulis merasa tertarik untuk membahas tentang hal-hal yang berkaitan dengan zakat profesi, khususnya cara istinbath hukumnya perspektif Yusuf al Qardawi.

Adapun yang hendak diungkap dalam tulisan ini adalah; bagaimana metode istinbath hukum zakat profesi perspektif pemikiran Yusuf al Qardawi? dan 
bagaimana implikasi output dari pemikiran tersebut terhadap pengembangan objek zakat di Indonesia?

\section{Metode Istinbath Hukum Islam dan Zakat Profesi}

1. Metode istinbath hukum Islam

Sebelum membahas tentang metode istinbath yang digunakan oleh al Qardawi dalam kaitannya dengan zakat profesi, lebih lanjut penulis akan uraikan hal-hal yang berkaitan dengan istinbath dalam hukum Islam.

Menurut ulama' Usul al Fiqh, suatu istinbath hukum memiliki beberapa prosedur nalar. Dalam istinbath hukum tidak dapat terlepas dari dua aspek pokok, yaitu: al qawaid al lughawiyyah al lafziyyah dan al qawaid al syar'iyyah al ma'nawiyah. Jika digunakan dalam berijtihad, maka cara tersebut dinamakan dengan al thuruq al lughawiyyah dan al thuruq al syar'iyyah atau al ma'nawiyyah (Hasbullah, 1964: 171).

a. Al Thuruq al lughawiyyah al lafdziyyah

Adapun yang dimaksud dengan al thuruq al lughawiyyah al lafziyyah dalam istinbath hukum adalah, cara memahami dan menafsirkan nash al Qurandan nash sunnah dengan menitikberatkan pada pengakajian lingkup lafaz nya. Penjabaran terhadap nash dibutuhkan karena dengan maksud untuk mengetahui tujuan-tujuan nash tersebut. Menurut Abdul Wahhab Khalaf, terdapat beberapa teori dalam al thuruq al lughawiyyah al lafziyyah yaitu (Khalaf, 1996: 229):

Pertama, teori dalam pengambilan makna nash mulai dilalah manthuq menurut Satria Effendi M. Zein, terbagi menjadi dua, yaitu; dilalah manthuq sharih dan dilalah manthuq ghoiru sharih, untuk yang terakhir ini menurut Musthafa Said terbagi menjadi tiga yaitu; iqtidau al nash,dilalatu al ima', dan isyaratu al-nash. Kedua, teori mafhum al mukhalafah (ex contrario), yang meliputi: mafhum al shifah, mafhum al ghayah (maxim), mafhum al syarthi (mafhum dengan syarat), mafhum al 'adad (bilangan), mafhum al laqab (mafhum dengan gelar/ atribut). Ketiga, teori tentang petunjuk yang jelas indikasi maknanya (wadih al dilalah), yang tingkatannya meliputi: zahir, dan nash; Keempat, teori tentang petunjuk yang samar atau tidak jelas indikasi maknanya (ghairu wadhih al dilalah), yang tingkatannya meliputi; al mujmal dan al mutasyabih. Kelima, teori tentang al 'amm dan al khas. Ketujuh, teori tentang lafaz mutlaq dan muqayyad (Khin, 1998: 139).

b. Al Thuruq al syar'iyyah/al ma'nawiyyah

Sedangkan al thuruq al syar'iyyah/al ma'nawiyyah adalah penarikan 
kesimpulan bukan pada nash secara langsung. Menurut Asymuni, terdapat beberapa metode pada al thuruq al ma'nawiyah, yaitu; qiyas, istihsan, mashlahah mursalah, 'urf, syar'u man qablana, dan qawl sahaby dan lain-lain (Asymuni, 1986: 01). Dengan metode ini para mujtahid menafsirkan nash dengan jalan memperluas cakupan maknanya kepada yang lebih luas yang tidak disebut oleh nash, dengan menggunakan dalil-dalil ijtihad (al Naim, 1990: 54).

Diantara metode ijtihad yang disepakati ulama' (khususnya Sunni) adalah qiyas. Pengertian qiyas menurut bahasa, berasal dari kata q-y-s, yang berarti mengukur. "qis rumh" atau "qas rumh" adalah ungkapan Arab yang berarti mengukur tombak atau lembing. Kata tersebut juga mempunyai akar kata lain q-w-s yang menunjukkan makna yang sama. Ungkapan qistu al sya'a bi ghairih (saya mengukur sesuatu dengan sesuatu lain yang menyerupainya) (Praja, 1995: 21).

Qiyas menurut bahasa berarti mengukur sesuatu dengan sesuatu (taqdir al syai'i bi ghoirihi). Mengukur sesuatu benda tersebut dengan sesuatu yang universal yang sesuai dengan benda itu dan sesuai pula dengan benda-benda lain yang sesuai dengannya (Djamil, 1997: 38).

Sedangkan secara istilah, ada berbagai definisi yang dirumuskan oleh para ulama. Diantaranya menurut al Ghazali dalam al Mushtashfa (al Ghazali, 1937: 214):

Artinya: Menanggungkan sesuatu yang diketahui kepada sesuatu yang diketahui dalam hal menetapkan hukum pada keduanya atau meniadakan hukum dari keduanya disebabkan ada hal yang sama antara keduanya, dalam penerapan hukum atau peniadaan hukum.

Lebih jauh, dia mengatakan bahwa qiyas juga disebut al nazhar wa al ijtihad (refleksi dan penalaran bebas), karena ia melibatkan refleksi; juga disebut dalil (petunjuk), karena ia menunjukkan ketetapan hukum, dan disebut i'tilal (sebab akibat), karena ia terdiri dari alasan hukum ('illat). Karena'illat (sebab) merupakan komponen utama qiyas, kadang-kadang qiyas juga disebut 'illat. Hal senada disampaikan oleh Qadhi Abu Bakar, qiyas menurutnya adalah (Qadhi, 1991:321):

Artinya: Menanggungkan sesuatu yang diketahui kepada sesuatu yang diketahui dalam hal menetapkan hukum pada keduanya atau meniadakan hukum dari keduanya disebabkan ada hal yang sama antara keduanya.

Lain lagi dengan Ibnu Subki dalam bukunya Jam'u al Jawami' yang memberikan definisi qiyas sebagai berikut (Subki, 2003: 80): 


\begin{abstract}
حمـل معلوم على معلوم لمسـاواته في علة حكمهـه عند الحامل Artinya: Menghubungkan sesuatu yang diketahui dengan sesuatu yang diketahui karena kesamaannya dalam 'illat hukumnya menurut pihak yang menghubungkan (mujtahid).
\end{abstract}

Dalam definisi itu, Ibnu Subki menambahkan catatan bahwa titik kesamaan antara yang asal (al ashlu) dengan cabang (furu') berdasarkan pandangan subjektif dari al qais (orang yang melakukan qiyas). Sedangkan menurut Wahbah al Zuhaili, qiyas yaitu menyatukan sesuatu yang tidak disebutkan hukumnya dalam nash dengan sesuatu yang disebutkan hukumnya oleh nash, disebabkan kesatuan'illat hukum antara keduanya (al Zuhaili, 1986: 601).

Berdasarkan pengertian terminologis qiyas yang beragam dari para ahli di atas, dapat disimpulkan bahwa qiyas sebagai penyamaan kasus yang tak terungkap oleh nash dengan kasus yang terungkap oleh nash, karena kesamaan nilai-nilai ('illat) syari'ah antara keduanya dalam rangka menerapkan hukum satu kasus atas lainnya.

Di dalam qiyas harus terdapat unsur-unsur sebagai berikut: pertama, al ashlu (hukum asal). Ahmad Hanafi menyebutnya "kasus asal", yaitu sesuatu yang di-nash-kan hukumnya yang menjadi ukuran atau tempat menyerupakan/ meng-qiyas-kan di dalam istilah pokok disebut al ashlu (الأصل) atau maqis 'alayh atau musyabbah bih () (المقيس عليه) (المشبه به kedua, al far'u (cabang), yaitu sesuatu yang tidak di-nash-kan hukumnya yang di serupakan atau yang di-qiyas-kan, dalam istilah ushul al fiqh hal ini di sebut al far'u (الفرع) atau al maqis (المقيس) atau al musyabbah (المشبه); ketiga, hukum asal (حكم الاصل), yaitu hukum syara' yang dinashkan pada pokok yang kemudian akan menjadi hukum pula bagi cabang; dan keempat, 'illat (العلة / ratio legis), yaitu sebab yang menyambungkan pokok dengan cabangnya (al Amidi, 2003: 241).

Lebih lanjut al Amidi menjelaskan, macam-macam qiyas dilihat dari kekuatan 'illat yang terdapat pada furu' dibandingkan dengan yang terdapat pada ashl, terdiri atas: 1). Qiyas aula, yaitu qiyas yang hukumnya pada furu' lebih kuat daripada hukum ashl, karena 'illat yang terdapat pada furu' lebih kuat dari yang ada pada ashl (al Amidi, 2003: 05). Seperti mengqiyaskan perbuatan memukul, kepada kata-kata yang kurang mengenakkan terhadap Ibu-Bapak karena 'illatnya menyakiti. Haramnya memukul orang tua lebih kuat daripada sekedar mengatakan kata-kata yang kurang mengenakan, seperti kata ah;2). Qiyas musawiy, yaitu 'illat yang terdapat pada yang diqiyaskan (furu') sama dengan 'illat yang ada pada tempat mengqiyaskan (asal), karena itu hukum keduanya sama. Seperti mengqiyaskan membakar harta anak yatim dengan 
memakannya, karena illatnya sama-sama menghabiskan; 3). Qiyas al adna, yaitu 'illat yang ada pada furu' lebih lemah dibandingkan dengan 'illat' yang ada pada ashl. Misalnya mengqiyaskan apel pada gandum dalam hal berlakunya riba fadl, karena keduanya mengandung 'illat yang sama, yaitu sama-sama jenis makanan.

Adapun macam-macam qiyas dilihat dari segi kejelasan 'illat yang terdapat pada hukum, terbagi atas: 1). Qiyas al jaliy, yaitu qiyas yang 'illatnya ditetapkan oleh nash bersamaan dengan hukum asal, atu nash tidak menetapkan 'illatnya, tetapi dipastikan bahwa tidak ada pengaruh perbedaan antar ashlu dengan furu'; 2). Qiyas khafiy, qiyas yang 'illatnya tidak disebutkan dalam nash. Contohnya, meng-qiyaskan pembunuhan dengan benda berat kepada pembunuhan dengan benda tajam dalam memberlakukan hukuman qishas, karena illatnya sama-sama pembunuhan sengaja dengan unsur permusuhan (al Amidi, 2003: 06).

Selanjutnya macam-macam qiyas dilihat dari segi keserasian illat dengan hukum, terbagi atas: 1). Qiyas al mu'ashsir, qiyas yang menjadi penghubung antara ashl dengan furu' ditetapkan melalui nash syarih atau ijma.' Contohnya, mengqiyaskan hak perwalian dalam menikahkan anak di bawah umur kepada hak perwalian atas hartanya, dengan 'illat belum dewasa. 'illat belum dewasa ini ditetapkan melalui ijma'; 2). Qiyas al mula'im, yaitu qiyas yang illat hukum ashnya mempunyai hubungan yang serasi. Misalnya mengqiyaskan pembunuhan dengan benda berat kepada pembunuhan dengan benda tajam. Illat pada hukum ashl mempunyai hubungan yang serasi (al Amidi, 2003: 07)

Sedangkan macam-macam qiyas dilihat dari segi dijelaskan atau tidaknya 'illat pada qiyas tersebut, terbagi atas: 1). Qiyas dalalah, yaitu 'illat yang ada pada qiyas menjadi dalil (alasan) bagi hukum, tetapi tidak diwajibkan baginya (furu'). Seperti mengqiyaskan wajib zakat pada harta anak-anak kepada harta orang dewasa yang telah sampai nishab, tetapi bagi anak-anak tidak wajib mengeluarkan zakatnya diqiyaskan pada haji yang tidak diwajibkan atas anakanak; 2). Qiyas al'illat, yaitu qiyas yang dijelaskan 'illat-nya dan 'illat itu sendiri merupakan motivasi bagi hukum ashl. Contohnya, mengqiyaskan minuman keras yang terbuat dari perasan selain anggur (nabiz) kepada khamar, karena kedua minuman tersebut samasam memiliki rangsangan yang kuat, baik pada ashl maupun pada furu'; 3). Qiyas al ma'na, yaitu qiyas yang di dalamnya tidak dijelaskan 'illatnya tetapi antara ashl dengan furu' tidak dapat dibedakan, sehingga furu' seakan-akan ashl, Contohnya, meng-qiyaskan membakar harta anak yatim dengan memakannya (al Amidi, 2003: 07).

Terakhir pembagian qiyas dilihat dari segi metode dalam menemukan 
'illat, terdiri atas: 1). Qiyas al ikhalah, yaitu qiyas yang 'illatnya ditetapkan melalui munasabah dan ikhalah; 2). Qiyas al-sibru, yaitu qiyas yang 'illatnya ditetapkan melalui metode al sibru wa al taqsim; 3). Qiyas al thard, yaitu qiyas yang illat-nya ditetapkan melalui metode thard; 4). Qiyas syabah, yaitu qiyas yang 'illatnya menggunakan metode syabah, (mempunyai keserupaan) (al Amidi, 2003: 07).

2. Kajian tentang zakat profesi

Istilah profesi menurut kamus ilmu pengetahuan adalah pekerjaan dengan keahlian khusus sebagai mata pencaharian (Kohar, 1988: 200). Profesi juga berarti suatu bidang pekerjaan yang berdasarkan pendidikan keahlian tertentu (Salim, 199: 1192). Pada umumnya istilah profesi dimaksudkan sebagai suatu keahlian mengenai bidang tertentu, di mana perolehannya didahului oleh pendidikan dengan penguasaan pengetahuan, ilmu dan ketrampilan. Dalam hal ini, suatu profesi merupakan suatu kegiatan yang dilakukan untuk memperoleh nafkah dengan suatu keahlian tertentu, bukan sekedar menyalurkan kesenangan atau hobi dan bukan pula sekedar kegiatan awam atau kuli.

Di dalam kamus bahasa Indonesia, disebutkan bahwa: profesi adalah bidang pekerjaan yang dilandasi pendidikan keahlian (ketrampilan, kejujuran dan sebaginya) tertentu. Profesional adalah yang bersangkutan dengan profesi, memerlukan kepandaian khusus untuk menjalankannya. Zakat profesi adalah zakat yang dikenakan kepada penghasilan para pekerja karena profesinya. Akan tetapi, pekerja profesi mempunyai pengertian yang luas, karena semua orang bekerja dengan kemampuannya, yang dengan kata lain mereka bekerja karena profesinya.

Dari definisi diatas ada poin-poin yang perlu digaris bawahi berkaitan dengan profesi yang dimaksud, yaitu: Jenis usahanya halal; Menghasilkan uang relatif banyak; Diperoleh dengan cara yang mudah; Melalui suatu keahlian tertentu.

Dari kriteria tersebut dapat diuraikan jenis-jenis usaha yang berhubungan dengan profesi seseorang, apabila ditinjau dari bentuknya, usaha profesi tersebut bisa berupa: 1). Usaha fisik, seperti pegawai dan artis. 2). Usaha pikiran, seperti konsultan, desainer dan dokter. 3). Usaha kedudukan, seperti komisi dan tunjangan jabatan. 4). Usaha modal, seperti investasi.

Selanjutnya adalah pengertian zakat. Secara etimologi (bahasa) kata "zakat" diambil dari kata (al zakah), sedang lafaz (al zakah) berarti "tumbuh, baik, suci dan berkah”(Dahlan, 1996:1985). Syara' memakai kata tersebut untuk 
dua arti. Pertama, dengan zakat diharapkan akan mendatangkan kesuburan pahala. Kedua, zakat merupakan suatu kenyataan jiwa suci dari kikir dan dosa (Al Shiddieqy, 1984: 24).

Adapun menurut istilah ada beberapa pengertian yang sampaikan oleh beberapa ulama ahli fiqh (fuqaha) diantaranya:

عطاء جزاء من النصاب الى فقير ونحـوه غير متصف بمان بـانع شـرعى يمنع من الصرف اليه Artinya: Memberikan sesuatu bagian dari harta yang sudah sampai nishabnya kepada orang fakir dan lain-lainnya, tanpa ada halangan syar'i yang melarang untuk melakukannya"(al Syawkani, tt: 114).

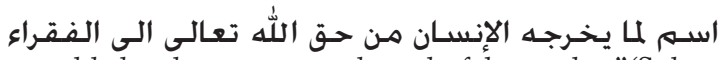

Artinya: Suatu hak Allah SWT yang dikeluarkan seseorang kepada fakir miskin"(Sabiq, 1983: 276).

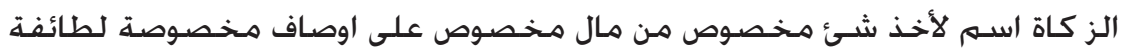

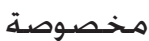

Artinya: Zakat adalah nama baik bagi pengambilan tertentu dari harta tertentu menurut sifat tertentu diberikan kepada golongan tertentu"(al Mawardi, tt: 71).

Dengan demikian kalau digabungkan maka secara istilahi menjadi zakat profesi, terminologi yang baru ini tentunya memiliki definisi pula, sebagaimana disebutkan dibawah ini; yaitu zakat yang diperoleh dari semua jenis penghasilan yang halal yang diperoleh setiap individu Muslim, apabila telah mencapai batas minimum terkena zakat (nishab) dan telah jatuh tempo (hawl) (Zuhdi, 1997:229).

Sedangkan menurut Didin Hafiduddin, zakat profesi adalah zakat yang dikenakan pada tiap pekerjaan atau keahlian tertentu, baik yang dilakukan sendirian maupun bersama orang lain atau dengan lembaga lain, yang mendatangkan penghasilan (uang) yang memenuhi nisab (batas minimum untuk berzakat) (Hafiduddin, 2004: 103).

Berdasarkan beberapa pengertian zakat profesi di atas, dapat disimpulkan bahwa zakat profesi adalah zakat yang dikeluarkan dari hasil usaha yang halal yang dapat mendatangkan hasil (uang) yang relatif banyak dengan cara yang mudah, melalui suatu keahlian tertentu dan sudah mencapai nishab.

\section{Pemikiran Yusuf al QardawiTentang Zakat Profesi}

1. Biografi, setting sosial dan politik al Qardawi

Saya tidak pernah berkeinginan atau berharap agar dilahirkan dan dibesarkan di sebuah kota besar seperti Kairo, yang merupakan tempat kelahiran Ahmad Amin; di Damaskus yang merupakan tempat kelahiran 'Ali Thahthawi, sehingga kami dapat bercerita panjang mengenai keistimewaan dan keindahan kota kelahiran kami. 
Kenyataannya, kami dilahirkan dan dibesarkan di sebuah kampung terpencil yang terdapat di pedalaman Mesir dan jauh dari hiruk pikuk kota modern (al Qardawi, 2003: 09).

Itulah sepenggal paragraf yang ditulis oleh al Qardawi ketika memulai tulisan yang menceritakan dirinya sendiri dalam buku autobiografinya. Pemilik nama lengkap Yusuf 'Abdullah al Qardawi ini dilahirkan pada tanggal 9 September 1926 di sebuah desa yang bernama Saftu Turab (Qadir, 1990: 16), daerah Mahallah al Kubra Provinsi al Garbiyah Republik 'Arab Mesir, dari kalangan keluarga yang taat beragama dan hidup sederhana.

Ayahnya adalah seorang petani yang wafat pada saat al Qardawi berusia dua tahun, sehingga ia dipelihara oleh pamannya dan hidup bergaul dengan putra putri pamannya yang dianggap sebagai saudara kandungnya sendiri. Saat berusia sepuluh tahun, ia belajar pada sekolah al Ilzamiyah pada pagi hari dan sore harinya ia belajar al Quran. Pada usia itu ia telah hafal al Quran dan menguasai ilmu tilawah. Kemudian ia melanjutkan pendidikannya ke Thanta dan menamatkan pendidikannya pada Fakultas Ushuluddin Universitas al Azhar pada tahun 1952/1953 dengan predekat terbaik. Setelah itu ia belajar bahasa Arab selama dua tahun dan memperoleh ijazah internasional dan sertifikat mengajar. Tahun 1957 ia melanjutkan karirnya di Ma'had al Buhuts wa al Dirasat al 'Arabiyah al Aliyah (Lembaga Tinggi Riset dan Kajian KeAraban). Tahun 1960 ia menamatkan studi pada Pascasarjana di Universitas al Azhar dengan konsentrasi Tafsir Hadits. Selanjutnya al Qardawi berhasil menyelesaikan pendidikannya pada program Doktor dengan disertasi fiqh al zakah pada tahun 1972 dengan predikat cumlaude.

Dalam pengembaraan ilmiahnya, al Qardawi banyak menelaah pendapat para ulama terdahulu seperti al Ghazali, Ibnu Taymiyyah, Ibnu Qayyim, Syaikh al Bakhi al Khawli, Muhammad 'Abdullah Darraz serta Syaikh Mahmud Syaltut (Qadir, 1990: 18). Ia juga sangat menghayati pengajaran dan perjuangan gurunya yang bernama Hasan al-Banna.

Pada masa kekuasaan raja Faruq tahun 1949, al Qardawi pernah dipenjarakan karena terlibat dalam pergerakan Ikhwanul Muslimin, pada bulan April 1956 ia ditangkap dan yang terakhir pada bulan Oktober 1956 ia dipenjarakan selama 2 tahun. Selanjutnya pada tahun 1961 al Qardawi pergi ke Qatar dan mendirikan madrasah Ma'had al Din yang kemudian berkembang menjadi Fakultas Syari'ah dan Universitas Qatar (Junaidi, 2004: 31).

Selama karirnya, al Qardawi pernah memegang berbagai jabatan penting, 
antara lain, yakni: 1). Dekan Fakultas Syariah dan Studi Islam di Universitas Qatar; 2). Direktur Kajian Sunnah dan Sirah di Universitas Qatar; 3). Anggota Lembaga Tertinggi Dewan Fatwa dan Pengawasan Syariah di Persatuan Bank Islam Internasional; 4). Pakar Fikih Islam di Organisasi Konferensi Islam; 5). Anggota/Pendiri Yayasan Kebajikan Islam Internasional; 6). Anggota Majelis Pengembangan Dakwah Islamiyah di Afrika (Junaidi, 2004: 31).

Disamping itu, al Qardawi banyak sekali membuahkan karangan yang berkualitas antara lain: figh al zakah; figh al nisa'; madkhal lima'rifati al Islam wa muqawwimatuh; al Halal wa al haram fi al Islam; bay'u al murabahah li al amir bi al-syira; fawaid al bunuk hiya al riba al muharram; al 'Aql wa al ilmi fi al Quranal karim; al Figh al islamy bayna al ashalah wa al tajdid; fatawa mu'asirah; al Ijtihad fi al syari'ati al islamiyyah; al ijtihad al mu'ashir bayna al indibat wa alimfirat; malamih al mujtama' al muslim allazi nunsyiduhu; al sunnah masdaran li al ma'rifah wa al hadarah.

\section{Pemikiran Yusuf al Qardawi tentang zakat profesi}

Islam tidak mewajibkan zakat atas seluruh harta benda, sedikit atau banyak, tetapi mewajibkan zakat atas harta benda yang sampai nishab dan bersih dari hutang, serta lebih dari kebutuhan pokok pemiliknya. Hal ini untuk menetapkan siapa yang termasuk golongan orang kaya yang wajib zakat. Zakat hanya dibebankan kepada orang-orang kaya tersebut.

Ketentuan tentang zakat yang sangat umum dalam al Quran, barangkali menjadi dasar dan pijakan sebagian golongan yang mendasarkan ijtihad dan istinbath hukumnya tentang zakat profesi menjadi sangat mungkin terjadi. Itulah juga kemungkinan besar yang mendasari seorang al Qardawi berani memunculkan dan menambahkan objek baru dalam masalah zakat, yaitu zakat profesi. Hal tersebut sebagaimana tergambar dalam pernyataan al Qardawi berikut ini:

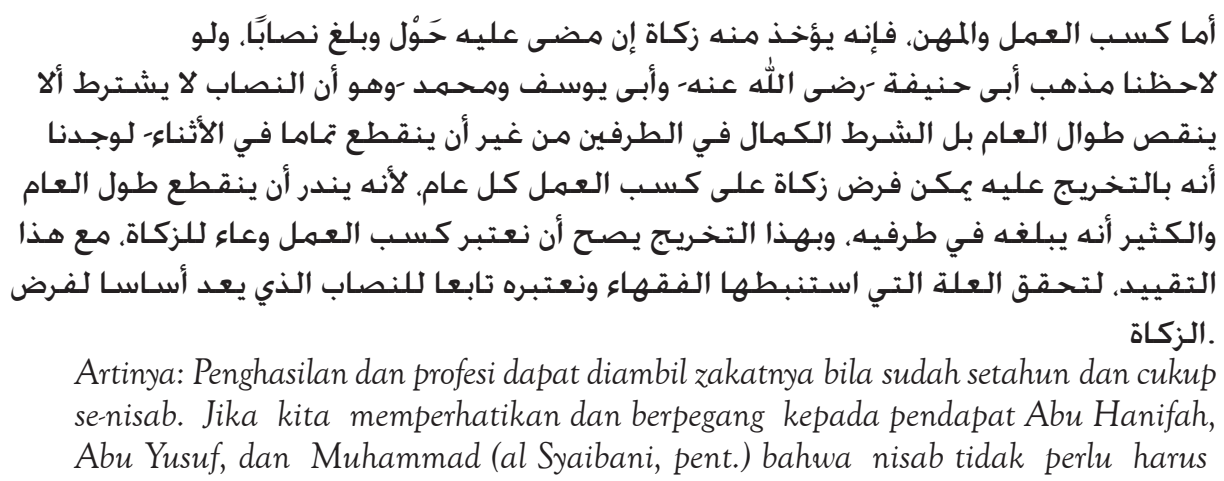

Ulul Albab Volume 16, No.1 Tahun 2015 
tercapai sepanjang tahun, tapi cukup tercapai penuh antara dua ujung tahun tanpa kurang di tengah-tengah kita dapat menyimpulkan bahwa dengan penafsiran tersebut memungkinkan untuk mewajibkan zakat atas hasil penghasilan setiap tahun, karena hasil itu jarang terhenti sepanjang tahun bahkan kebanyakan mencapai kedua sisi ujung tahun tersebut. Berdasar hal itu, kita dapat menetapkan hasil penghasilan sebagai sumber zakat, karena terdapatnya illat (penyebab), yang menurut ulama-ulama fikih sah, dan nisab, yang merupakan landasan wajib zakat (al Qardawi, 1973: 489).

Memang pendapat diatas pada dasarnya adalah kesimpulan dari ceramah yang disampaikan oleh Abdul Wahhab Khallaf tentang zakat di Damaskus pada tahun 1952. Namun pendapat tersebut dikutip oleh al Qardawi sebagai pijakan awal tentang ke-absahan zakat profesi dalam konteks modern saat ini, hal ini menunjukkan bahwa al Qardawi sependapat dan sepakat dengan pernyataan yang dikemukakan oleh Abdul Wahhab Khallaf tersebut.

Hal ini dibuktikan dengan pernyataan al Qardawi di lain tempat, yang inti dan kesimpulannya adalah sama dengan kesimpulan dari ceramah Abdul Wahhab Khallaf tersebut. Sebagai pelengkap, berikut ini statemen al Qardawi tentang zakat profesi tersebut:

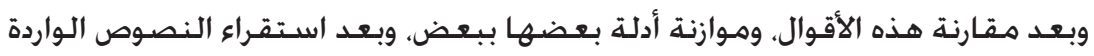

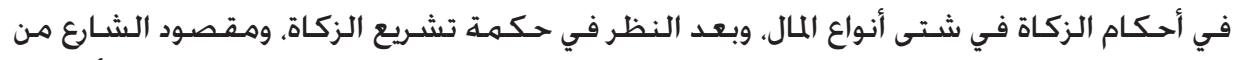

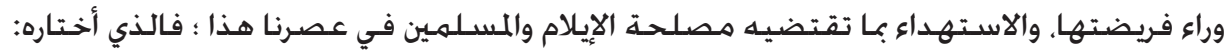

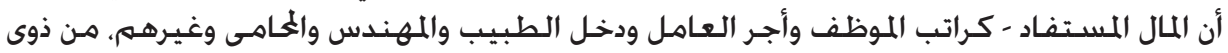

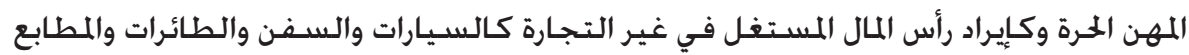

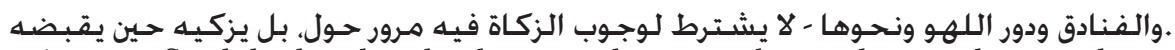
Artinya: Setelah diperbandingkan pendapat-pendapat di atas dengan alasan masing-masing, diteliti nash-nash yang berhubungan dengan status zakat dalam bermacam-macam kekayaan, diperhatikan hikmah dan maksud pembuat syariat mewajibkan zakat, dan diperhatikan pula kebutuhan Islam dan umat Islam pada masa sekarang ini, maka saya berpendapat harta hasil usaha seperti gaji pegawai, upah karyawan, pendapatan dokter, insinyur, advokat dan yang lain yang mengerjakan profesi tertentu dan juga seperti pendapatan yang diperoleh dari modal yang diinvestasikan di luar sektor perdagangan, seperti pada mobil, kapal, kapal terbang, percetakan, tempattempat hiburan, dan lain-lainnya, wajib terkena zakat persyaratan satu tahun dan dikeluarkan pada waktu diterima(al Qardawi, 1973: 505).

Namun demikian, dalam proses penetapan dan istinbath hukum zakat profesi sebagaimana yang dikehendaki oleh al Qardawi tidak semudah membalikkan telapak tangan, ada sederetan ahli hukum Islam yang menentang 
hal tersebut. Lantas, apakah harus terhenti sampai di sini, padahal problem zakat membutuhkan penanganan yang cukup serius, secara khusus bila objek zakat diperbaharui konsensus hukumnya, maka ketika umat Islam menemukan objek zakat baru, secara otomatis dana zakat yang akan dikelola untuk penanganan kemiskinan umat juga bertambah.

Dalam keadaan seperti ini, al Qardawi berpendapat:

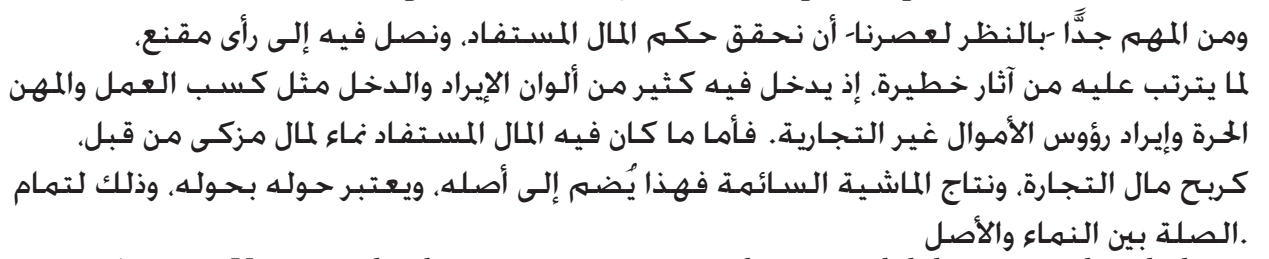

Artinya: Yang mendesak, mengingat zaman sekarang adalah menemukan hukum yang pasti «harta penghasilan» itu, oleh karena terdapat hal-hal penting yang perlu diperhatikan, yaitu bahwa hasil penghasilan, profesi, dan kekayaan non-dagang dapat digolongkan kepada «harta penghasilan» tersebut. Bila kekayaan dari satu kekayaan, yang sudah dikeluarkan zakatnya, yang di dalamnya terdapat «harta penghasilan» itu, mengalami perkembangan, misalnya laba perdagangan dan produksi binatang ternak maka perhitungan tahunnya disamakan dengan perhitungan tahun induknya. Hal itu karena hubungan keuntungan dengan induknya itu sangat erat (al Qardawi, 1973: 491).

Dari keterangan di atas, dapat diketahui bahwa menurut al Qardawi, mengingat keberlangsungan hidup dan kompleksitas permasalahan hukum zakat profesi, maka yang harus diperhatikan adalah memberi kepastian akan adanya hukum yang jelas dan memberi kepastian pada masalah hukum zakat profesi, keadaan tidak adanya ketetapan hukum yang pasti pada kasus hukum zakat profesi tidak dibiarkan berlarut-larut, harus solusi yang jelas dan mengakhiri permasalahan ini, hal itu tentunya dengan cara beristinbath dan memberi hukum yang jelas tentang zakat profesi berikut juga akibat turunan yang dimunculkan dari istinbath tersebut, seperti nishabnya zakat profesi dan lain sebagainya.

\section{a. Profesi yang wajib dizakati}

Secara umum, dari beberapa hal yang penulis kutip dalam pernyataan al Qardawi, dapat disimpulkan juga, bahwa penghasilan atau profesi yang wajib dizakati selain yang sudah disebutkan syara' dan hadits Nabi secara ekplisit, maka dibagi menjadi dua bagian, yaitu kasbu al 'amal dan mihanu al-hurrah. Kasbu al'amal adalah pekerjaan seseorang yang tunduk pada perseroan atau perseorangan dengan mendapatkan upah. Mihanu al hurrah adalah pekerjaan 
bebas, tidak terikat pada orang lain (al Qardawi, 1996: 459).

Dari istilah di atas dapat dipetakan, mihan al hurrah dapat saja meliputi penghasilan yang diperoleh melalui berikut ini: konsultan, notaris, advocat, dokter spesialis, dan lain sebagainya. Sedangkan kasbu al 'amal dapat saja meliputi beberapa penghasilan yang diperoleh dari pekerjaan berikut ini: pilot, nahkoda, masinis, direktur perusahaan, komisaris perusahaan, pegawai negeri goloangan atas, anggota DPR, menteri, presiden, hakim agung, hakim MK, komisioner di lembaga pemerintahan, lembaga pemerintah non struktural dan lembaga Negara serta berbagai pekerjaan yang sejenisnya.

Dari ulasan tersebut, seakan dapat dipahami bahwa al Qardawi berpendapat; kategori zakat profesi (yang wajib dizakati) adalah segala macam pendapatan yang didapat bukan dari harta yang sudah dikenakan zakat (al Qardawi, 1996: 459). Artinya, zakat profesi didapat dari hasil usaha manusia yang mendatangkan pendapatan dan sudah mencapai nishab. Bukan dari jenis harta kekayaan yang memang sudah ditetapkan kewajibannya melalui al Qurandan hadits Nabi, seperti hasil pertanian, peternakan, perdagangan, harta simpanan (uang, emas, dan perak), dan harta rikaz.

Termasuk kategori zakat profesi adalah upah dan gaji yang dihasilkan seseorang dari bekerja, sebagaimana hal tersebut dikatakan al Qardawi berikut ini:

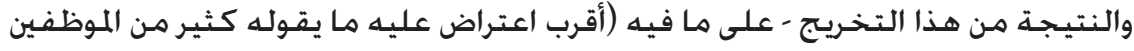

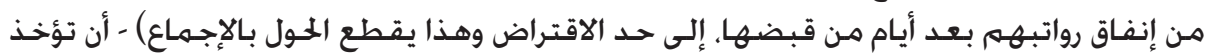

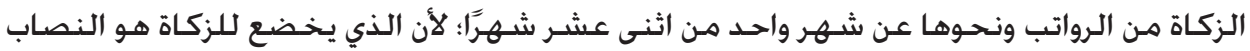
Artinya: Akibat dari tafsiran itu, kecuali yang menentang, - adalah bahwa zakat wajib dipungut dari gaji atau semacamnya sebulan dari dua belas bulan. Karena ketentuan wajib zakat adalah cukup nisab penuh pada awal tahun atau akhir tahun. Yang menarik adalah pendapat guru-guru besar tentang hasil penghasilan dan profesi dan pendapatan dari gaji atau lain-lainnya di atas, bahwa mereka tidak menemukan persamaannya dalam fikih selain apa yang dilaporkan tentang pendapat Ahmad tentang sewa rumah diatas. Tetapi sesungguhnya persamaan itu ada yang perlu disebutkan di sini, yaitu bahwa kekayaan tersebut dapat digolongkan kepada kekayaan penghasilan, yaitu kekayaan yang diperoleh seseorang Muslim melalui bentuk usaha baru yang sesuai dengan syariat agama. Jadi pandangan fikih tentang bentuk penghasilan itu adalah, bahwa ia adalah "harta penghasilan"(al Qardawi, 1973: 491).
} 
Intinya, kewajiban zakat profesi merupakan kewajiban baru dari hasil ijtihad ulama yang belum ditetapkan sebelumnya, melalui dalil al Quran yang umum ataupun melalui inspirasi Sunnah yang sejalan dengan prinsip al Quran tersebut.

\section{b. Nishab zakat profesi}

Kita sudah mengetahui, bahwa Islam tidak mewajibkan zakat atas seluruh harta benda, sedikit atau banyak, tetapi mewajibkan zakat atas harta benda yang mencapai nisab, bersih dari hutang, serta lebih dari kebutuhan pokok pemiliknya. Hal itu untuk menetapkan siapa yang tergolong seorang kaya yang wajib zakat karena zakat hanya dipungut dari orang-orang kaya tersebut, dan untuk menetapkan arti "lebih" ('afw) yang dijadikan al Quran sebagai sasaran zakat tersebut. Allah berfirman "mereka bertanya kepadamu tentang apa yang mereka nafkahkan", maka katakanlah: "yang lebih dari keperluan” (QS al Baqarah: 219). Oleh karena itu Rasulullah juga bersabda: "kewajiban zakat hanya bagi orang kaya". Hal itu sudah ditegaskan dalam syarat-syarat kekayaan yang wajib zakat. Bila zakat wajib dikeluarkan bila cukup batas nisab, maka berapakah besar nisab dalam kasus ini?

Ketika membahas tentang nishab zakat profesi ini, pada mulanya al Qardawi mengutip pendapat Muhammad al Ghazali, yang cenderung menqiyaskan zakat profesi dengan zakat al zuru' (zakat tanaman dan buah-buahan) (al Qardawi, 1973: 491), berikut ini narasi kutipan al Qardawi tersebut;

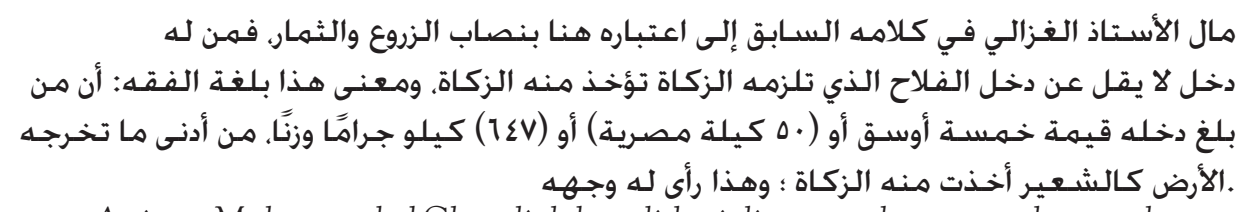

Artinya: Muhammad al-Ghazali dalam diskusi diatas cenderung untuk mengukurnya menurut ukuran tanaman dan buah-buahan. Seseorang yang memiliki pendapatan tidak kurang dari pendapatan seorang petani yang wajib mengeluarkan zakat maka orang itu wajib mengeluarkan zakatnya. Artinya, siapa yang mempunyai pendapatan yang mencapai lima wasaq (50 kail Mesir) atau $653 \mathrm{~kg}$, dari yang terendah nilainya yang dihasilkan tanah seperti gandum, wajib berzakat, dan ini adalah pendapat yang benar.

Menurut Muhammad al Ghazali, nishab zakat profesi sayogyanya disamakan dengan nisabnya zakat tanaman dan buah-buahan, sebagai pelengkap, dia memeberi penjelasan, "siapapun yang mempunyai pendapatan yang mencapai (senilai) $653 \mathrm{~kg}$ (padi), maka wajib berzakat”. Menyamakan nishab zakat profesi 
dengan nishabnhya zakat pertanian seperti pendapat ini, adalah pilihan yang moderat diantara beberapa alternatif yang lain, walaupun sebenarnya masih ada alternatif-alaternatif lain yang dapat dirumuskan terkait dengan nishab zakat profesi ini.

Diantara alternatif-alternatif tersebut sebagaimana yang dirumuskan dan dipilih oleh al Qardawi dalam menetapkan rumusan nishab zakat profesi, adalah mensamakannya dengan nishab zakat emas/perak, hal tersebut sebagaimana dikatakan al Qardawi berikut ini:

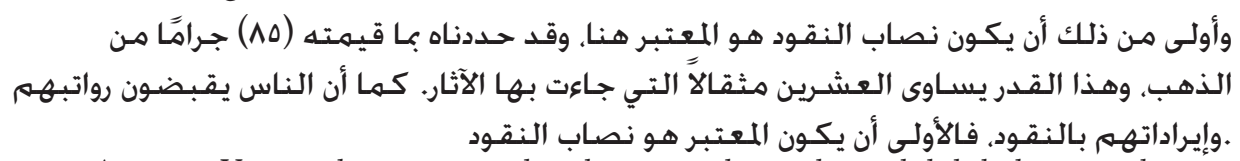

Artinya: Yang paling penting dari besar nisab tersebut adalah bahwa nisab uang diukur dari nisab tersebut yang telah kita tetapkan sebesar nilai 85 gram emas. Besar itu sama dengan dua puluh misqal hasil pertanian yang disebutkan oleh banyak hadits. Banyak orang memperoleh gaji dan pendapatan dalam bentuk uang, maka yang paling baik adalah menetapkan nisab gaji itu berdasarkan nisab uang (al Qardawi, 1973: 513).

Dari keterangan tersebut dapat diketahui, al Qardawi berpendapat bahwa orang memperoleh gaji dan pendapatan dalam bentuk uang, maka yang paling baik adalah menetapkan nishab gaji itu berdasarkan nishab uang (al Qardawi, 1996: 482). Oleh karenanya, berdasarkan pendapat al Qardawi tersebut nishab dan prosentase zakat profesi adalah disamakan dengan zakat uang, emas, dan perak senilai 85 gram dan kadarnya 2,5\%.

Sistem yang dipergunakan dalam pengeluaran zakatnya adalah dengan mengumpulkan gaji atau penghasilan yang diterima berkali-kali dalam waktu tertentu sampai mencapai nisab (85 gr emas) (al Qardawi, 1973: 484). Hal ini dapat ditemukan pada kasus nishab pertambangan, di mana ulama-ulama fiqh berpendapat hasil yang diperoleh dari waktu ke waktu yang tidak pernah terputus di tengah akan melengkapi untuk mencapai nishab.

Maka dari itu, dapat ditentukan bahwa satu tahun merupakan suatu kesatuan, menurut pandangan syari'at dan menurut pandangan ahli perpajakan. Oleh karenanya, ketentuan setahun diberlakukan dalam zakat. Maka zakat penghasilan bersih dari seorang pegawai dan golongan profesi dapat diambil dari dalam setahun penuh jika pendapatan tersebut sudah mencapai nishab (Ibid).

Masih menurut al Qardawi, zakat profesi tersebut diambilkan dari sisa pendapatan bersih setahun, yang dimaksudkan supaya bila ada hutang 
dan biaya hidup terendah serta yang menjadi tanggungan seseorang bisa dikeluarkan. Karena biaya terendah kehidupan seseorang merupakan kebutuhan pokok seseorang (Ibid). Senada dengan al Qardawi, Nukthoh Arfawi Kurde mengatakan bahwa pendapatan bersih adalah pendapatan kotor dikurangi jumlah pengeluaran untuk kehidupan layak; untuk makanan, pakaian, cicilan rumah tangga, dan lain-lain (Kurde, 2005: 29).

\section{Metode istinbath hukum zakat profesi menurut al Qardawi}

a. Dasar hukum zakat profesi

Mengenai istinbath hukum tentang kewajiban membayar zakat profesi, terlebih dahulu mencari landasan hukumnya pada nash-nash al Quran. Oleh karenanya, ketika mencari landasan hukum kewajiban membayar zakat profesi, al Qardawi antara lain mendasarkannya pada al Quran surat al Baqarah: 267 yang berbunyi:

Artinya: Hai orang-orang yang beriman, nafkahkanlah (di jalan Allah) sebagian dari hasil usahamu yang baik-baik dan sebagian dari apa yang kami keluarkan dari bumi untuk kamu, dan janganlah kamu memilih yang buruk-buruk lalu kamu menafkahkan daripadanya, Padahal kamu sendiri tidak mau mengambilnya melai1nkan dengan memincingkan mata terhadapnya, dan ketahuilah, bahwa Allah maha kaya lagi maha terpuji (Fahruddin, 1992: 213).

Al Qardawi menafsirkan keumuman lafaz "ma kasabtum" dalam ayat di atas yang berarti mencakup segala macam usaha; perdagangan atau pekerjaan dan profesi, sedangkan jumhur ulama fiqh mengambil keumuman maksud surat al Baqarah: 267 tersebut di samping sebagai landasan wajibnya zakat perdagangan juga menjadikan wajibnya zakat atas usaha profesi. Sesuai ayat tersebut di atas, kata "anfiqu" memfaedahkan wajib, karena kata "anfiqu" merupakan kalimat perintah (fi'il amar) dari kata kerja masa lalu (fi'il mâdlî) "anfaqa”, maka sesuai dengan kaidah ushul al-figh: al-ashlu fi al-amri li al-wujub, yang artinya "pada asalnya perintah itu berfaedah wajib" (Usman, 2002: 15).

Berikut ungkapan resmi al Qardawi tentang ayat tersebut:

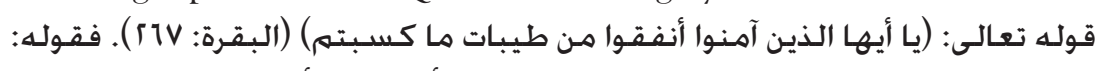

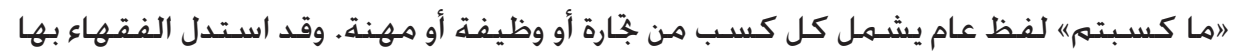

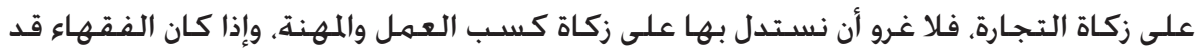

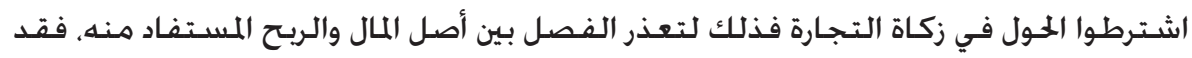

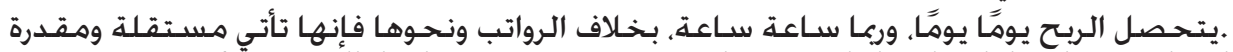
Artinya: firman Allah «hai orang-orang yang beriman keluarkanlah sebagian hasil usaha kalian.» (al-Baqarah: 267) kata mâ kasabtum merupakan kata umum yang 
artinya mencakup segala macam usaha: perdagangan, atau pekerjaan dan profesi. Para ulama fikih berpegang kepada keumuman maksud ayat tersebut sebagai landasan zakat perdagangan, oleh karena itu kita tidak perlu ragu memakainya sebagai landasan zakat penghasilan dan profesi. Bila para ulama fikih telah menetapkan setahun sebagai syarat wajib zakat perdagangan, maka itu berarti bahwa antara pokok harta dengan laba yang dihasilkan tidak boleh dipisahkan karena laba dihasilkan dari hari ke hari bahkan dari jam ke jam. Lain halnya dengan gaji atau sebangsanya yang diperoleh secara utuh, tertentu dan pasti (al Qardawi, 1973: 506).

Dari ungkapan al Qardawi diatas dapat dikatakan, bahwa dalam menetapkan wajibnya zakat profesi dapat mendasarkan pada QS al Baqarah 267, secara umum ayat tersebut juga digunakan oleh fuqaha (ahli fiqh) dalam menetapkan zakat perdagangan, maka menurut al Qardawi kita tidak perlu lagi untuk menjadikan ayat itu juga sebagai dasar wajibnya zakat profesi. Walaupun redaksi yang digunakan ayat tersebut adalah redaksi umum ('amm), namun demikian menurut al Qardawi tetap dapat digunakan sebagai landasan teologis atas kewajiban zakat profesi bagi setiap Muslim.

Selain melalui ayat tersebut, dalam menetapkan dasar hukum dan landasan teologis hukum zakat profesi, al Qardawi juga menggunakan dasar keumuman makna hadits yang diriwayatkan oleh al Bukhari berikut ini:

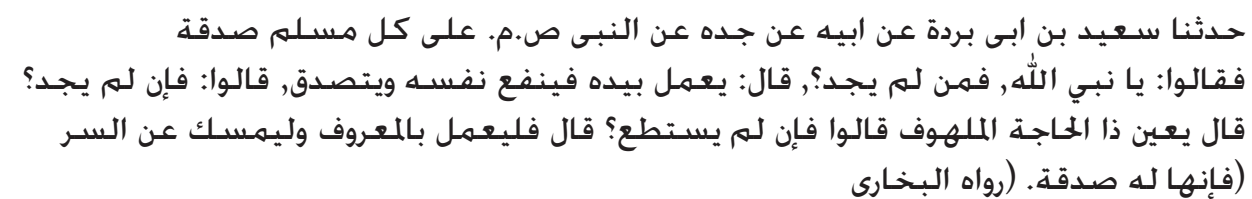

Artinya: Setiap orang Muslim wajib bersedekah, mereka bertanya: "wahai Nabi Allah, bagaimana yang tidak berpunya? Nabi menjawab: "bekerjalah untuk mendapat sesuatu untuk dirinya, lalu bersedekah". Mereka bertanya kembali: "kalau tidak menemukan pekerjaan? Nabi menjawab: "menolong orang yang membutuhkan dan terdzolimi". Mereka bertanya kembali: "kalau tidak dapat melakukan itu? Nabi menjawab: "kerjakan kebaikan dan tinggalkan keburukan, hal itu merupakan sedekah (al Bukhari, 2001: 292).

Al Qardawi menafsirkan keumuman dari makna hadits tersebut di atas bahwa zakat wajib atas penghasilan sesuai dengan tuntunan Islam yang menanamkan nilai-nilai kebaikan, kemauan, berkorban, belas kasihan, dan suka memberi dalam jiwa seorang muslim. Untuk itu Nabi mewajibkan pada setiap Muslim mengorbankan sebagian harta penghasilannya atau apa saja yang bisa ia korbankan.

Memang secara sepintas hadits diatas sangat umum sekali aspek yang 
membicarakan tentang zakat profesi, akan tetapi teradapat kata kunci yang dapat dijadikan landasan normativ sebagai pijakan dalam penetapan kepastian adanya pensyariatan zakat profesi. Adapun kata kuncinya tersebut terdapat pada kalimat berikut ini;

.......... يعمل بيده فينفع نفسـه ويتصدا....

Artinya: bekerjalah untuk mendapat sesuatu untuk dirinya, lalu bersedekah.

Maksud dari ungkapan nabi tersebut adalah, bahwa suatu keharusan bagi seorang Muslim untuk memiliki aktifitas/pekerjaan yang dapat memberikan kemanfaatan pada diri sendiri (keluarga atau orang yang menjadi tanggungannya), baru kemudian melaksanakan bentuk tuntutan zakat (profesi) bila harta yang dihasilkan dari bekerja tersebut lebih untuk memenuhi kebutuhan-kebutuhan pokoknya. Sebagaimana penjelasan hadits tersebut di bawah ini:

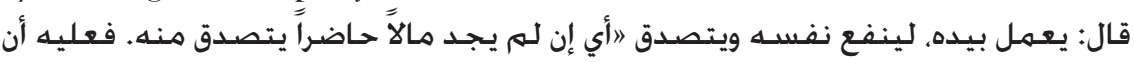

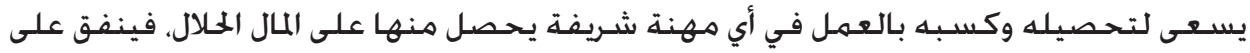
انفسـه ويتصدي لتحق على غيره

Artinya: Nabi bersabda: seseorang (tersebut) hendaknya bekerja supaya memberi kemanfatan pada dirinya, dan (dapat) bersedekah (berzakat) (Qasim, 1990: Juz: III, 27).

Bahkan kalau dipahami secara menyeluruh zhahir-nya makna hadits tersebut menganjurkan kepada tiap muslim agar wajib bersedakah (zakat), melalui bentuk aktifitas pekerjaan dan kreatifitas yang ditekuni, seseorang yang tidak mampu bersedekah (zakat) harusnya bekerja dengan keras, agar menjadi orang yang masuk kategori wajib berzakat dari hasil usaha dan kerjanya.

Lantas dari mana kata sedekah (صدقة) tersebut dimaknai dengan zakat (profesi), kalau tidak dijelaskan secara gamblang tentunya akan menyebabkan kesalahpahaman pada pembaca. Lafazd yang digunakan dalam narasi hadits tersebut memang menggunakan kata sedekah (صدقة), akan tetapi menghasilkan makna zakat (profesi), karena adanya anjuran dari nabi SAW sebagai perwakilan dari syari' yang memerintahkan setiap muslim untuk bersedakah (zakat), implikasinya sedekah yang dianjurkan nabi SAW, menjadi sejenis kewajiban bagi setiap muslim, padahal secara syar'i sedekah (صدقة) tidak berdimensi ijab dalam kategori tuntutanya, hanya pada tingkatan sunnah (mustahab). Maka, walaupun lafazd yang digunakan disini adalah sedekah (صدقة), tapi maknanya adalah zakat (profesi), karena mengandung tuntutan ijab (wajib), berdasarkan perintah dari syari' tersebut.

Metode istinbath hukum zakat profesi perspektif al Qardawi 
Pada pembahasan sebelumnya telah dijelaskan bahwa dasar hukum yang digunakan oleh al Qardawi dalam menetapkan hukum zakat profesi (penghasilan), maka pada kajian selanjutnya akan diuraikan metode yang digunakan oleh al Qardawi dalam mengkaji dasar hukum tersebut, sehingga muncul hukum wajibnya zakat profesi sebagai objek zakat yang harus dikeluarkan oleh setiap muslim yang telah memenuhi syaratnya sebagai muzakki.

Berikut ini ungkapan al Qardawi terkait dengan metode yang digunakan dalam istinbath hukum zakat profesi:

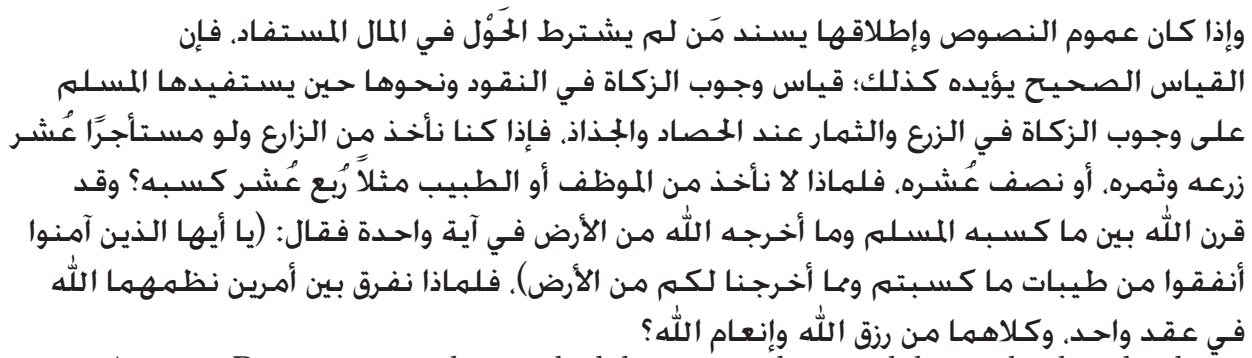

Artinya: Di samping nash yang berlaku umum dan mutlak memberikan landasan kepada pendapat mereka yang tidak menjadikan satu tahun sebagai syarat harta penghasilan wajib zakat, qiyas yang benar juga mendukungnya. Kewajiban zakat uang atau sejenisnya pada saat diterima seorang Muslim diqiyaskan dengan kewajiban zakat pada tanaman dan buah-buahan pada waktu panen. Maka bila kita memungut dari petani meskipun sebagai penyewa, sebanyak sepersepuluh atau seperdua puluh hasil tanaman atau buah-buahannya, mengapakah kita tidak boleh memungut dari seorang pegawai atau seorang dokter, umpamanya, sebanyak seperempat puluh penghasilannya? Apabila Allah menyatukan penghasilan yang diterima seseorang Muslim dengan hasil yang dikeluarkan Allah dari tanah dalam satu ayat, yaitu "hai orang- orang yang beriman keluarkanlah sebagian penghasilan kalian dan sebagian yang kami keluarkan untuk kalian dari tanah," mengapa kita membeda-bedakan dua masalah yang diatur Allah dalam satu aturan sedangkan kedua-duanya adalah rezeki dan nikmat dari Allah? (al Qardawi, 1973: 491).

Dari redaksi yang disebutkan diatas, secara implisit al Qardawi menyebutkan, bahwa nalar argumentasi dan metode yang digunakan dalam menghukumi tentang adanya kewajiban zakat untuk jenis profesi apapun bagi setiap Muslim adalah qiyas. Selain qiyas, landasan, basis dan dasar argumentasi yang digunakan oleh al Qardawi dalam penetapan hukum zakat profesi adalah keadilan yang proporsional, hal tersebut nammpak terlihat ketia al Qardawi menyebutkan zakat profesi serta memperbandingkannya dengan jenis kategori zakat yang lain, seperti padi, tanaman dan lain sebagainya.

Penggunaan qiyas dalam penetapan zakat profesi ini, diqiyaskan dengan 
zakatnya emas dan perak (Latifah, 2010: 94). Sedangkan dalam masalah haulnya (sebagai alternatif lain), al Qardawi mengqiyaskan dengan zakatnya buahbuahan dan tanaman (zakat al tsimar wa al zuru'), sehingga nishab-nya adalah 5 wasaq $(750 \mathrm{~kg}$ ) beras, dengan kadar dan ukuran 5\% (jika perawatannya menggunakan irigasi) atau 10\% (jika perwatannya tanpa irigasi).

Sebagai tambahan, al Qardawi juga menjelaskan tentang adanya aspek keadilan dalam penentuan kewajiban zakat profesi bagi setiap Muslim. Karena secara esensial, zakat adalah ibadah yang berkaitan dengan harta benda. Seseorang yang telah memenuhi syarat-syaratnya dituntut untuk menunaikannya, bukan semata-mata atas dasar kemurahan hatinya, tetapi kalau perlu bahkan dengan tekanan penguasa (Shihab, 1999: 323).

Berikut ini adalah statetemen al Qardawi tentang keadilan tersebut:

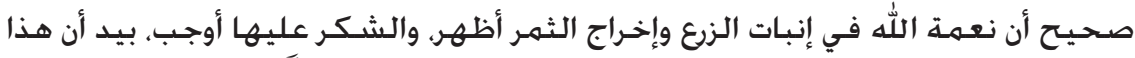

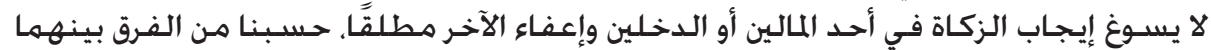

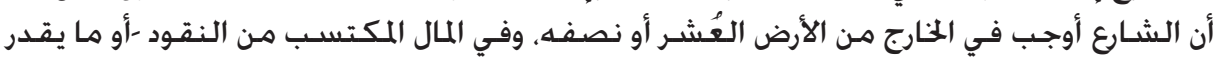

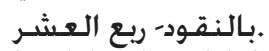
Artinya: benar, bahwa nikmat Allah dalam hasil tanaman dan buah-buahan lebih kentara dan mensynkurinya lebih wajib, namun demikian tidak berarti bahwa salah satu pendapatan tersebut tegas wajib zakat sedangkan yang satu lagi tidak. Perbedaannya cukup dengan bahwa pembuat syariat mewajibkan zakat dari hasil tanah sebesar sepersepuluh atau seperdua puluh sedangkan pada harta penghasilan berupa uang atau yang senilai dengan uang-sebanyak seperempat puluh (al Qardawi, 1973: 507).

Hal lain yang harus dipahami adalah, bahwa pensyari'atan zakat di dalam Islam menunjukkan bahwa Islam sangat memperhatikan masalah-masalah kemasyarakatan, terutama nasib orang-orang yang lemah secara ekonominya. Sehingga mendekatkan hubungan kasih sayang antara sesama manusia dalam mewujudkan kata-kata bahwa Islam itu bersaudara, saling membantu, dan tolong-menolong; yang kuat menolong yang lemah, yang kaya membantu yang miskin.

Salah satu tujuan zakat yang terpenting adalah mempersempit ketimpangan ekonomi dalam masyarakat sampai batas yang seminimal mungkin (Muhammad, 2002: 17). Tujuannya adalah menjadikan perbedaan ekonomi di antara masyarakat secara adil dan seksama, sehingga yang kaya tidak semakin kaya (dengan mengeksploitasi anggota masyarakat yang miskin) dan yang miskin tidak semakin miskin.

Makna filosofi yang bisa digali dari adanya kewajiban zakat profesi kiranya mengacu dari garis besar tujuan disyariatkannya zakat. Namun dalam 
kesempatan lain, kewajiban zakat pada semua hasil kerja profesi menunjukkan tingkat apresiasi yang lebih pada sumber-sumber harta yang wajib dizakati yang muncul di masa setelah Nabi.

\section{Analisis Metode Istinbath Hukum Zakat Profesi dan Implikasinya terhadap Pengembangan Objek Zakat di Indonesia}

1. Analisis metode istinbath hukum zakat profesi

Dari penjelasan yang telah penulis uraikan di atas, dapat dipahami bahwa metode istinbath yang digunakan oleh al Qardawi dalam menetapkan kewajiban zakat profesi adalah qiyas. Penggunaan qiyas sebagai basis dan dasar metode penetapan hukum zakat profesi dalam khazanah hukum Islam sebenarnya bukan merupakan hal baru, hal itu sebagaimana dikemukakan oleh beberapa para sarjana hukum Islam yang konsen dibidang perzakatan dan sejenisnya.

Didin Hafiduddin merupakan diantara orang yang menggunakan metode qiyas dalam penetapan adanya zakat profesi bagi orang yang beragama Islam, akan tetapi dalam qiyas yang digunakannya adalah qiyas syabah (Hariyanto, 2006: 59), yaitu; mempersamakan satu furu' dengan dua ashlu. Ini bermakna, dari segi nishab zakat profesi disamakan dengan zakat pertanian dan dari segi kadarnya disamakan dengan zakat emas, dan perak. Ukuran nishabnya adalah senilai dengan $524 \mathrm{Kg}$ beras dan kadar atau prosentase zakatnya adalah 2,5\%. Karena disamakan dengan zakat pertanian, zakat profesi dikeluarkan langsung seketika setelah menerima pendapatan atau penghasilan dari usaha profesi.

Muhammad al Ghazali misalkan, termasuk ulama' kontemporer yang mewajibkan adanya zakat profesi, dengan kata lain; pada penghasilan berupa jasa dikeluarkan zakatnya dan nishabnya dipersamakan dengan nishab pertanian, yaitu 5 wasaq sukatan atau $653 \mathrm{Kg}$ gandum. Penganalogian zakat profesi dengan zakat pertanian tersebut menurut Muhammad al Ghazali adalah bahwa: tidak dapat dibayangkan jika Islam mewajibkan zakat kepada petani yang berpenghasilan lima wasaq gandum $(653 \mathrm{~kg})$, sedangkan yang bukan petani tidak membayar zakat meskipun penghasilannya jauh lebih banyak daripada penghasilan petani. Jadi berdasarkan pendapat tersebut zakat setiap penghasilan sesuai dengan ukuran beban pekerjaan atau pengusahaannya (Hariyanto, 2006: 54).

Walaupun sama-sama menggunakan metode qiyas dalam istinbath hukum zakat profesi, al Qardawi berbeda dengan Hafiduddin dalam aplikasi qiyasnya. Dalam implementasi qiyas nya, maqis 'alayh (sesuatu yang dijadikan 
sandaran dalam qiyas (al aslu), yang digunakan oleh al Qardawi berbeda dengan intelektual kontemporer sebelumnya. Sebagai gambaran, berikut ini simulasi dan abtraksi qiyas yang digunakan al Qardawi pada kajian istinbath hukum zakat profesi;

Pertama, al ashlu/al maqis'alayh (sandaran). Pengertian dari al aslu ini adalah sesuatu yang dijadikan sandaran dalam meng-qiyaskan sesuatu. Maka dapat difahami, bahwa al ashlu dalam kajian ini adalah zakat emas dan perak, yang digunakan al Qardawi sebagai sandaran memunculkan hukum zakat profesi.

Kedua, al far'u / maqis (cabang). Yaitu sesuatu yang diqiyaskan, atau dengan kata lain; suatu masalah yang akan diqiyaskan disamakan dengan al ashlu (musyabbah). Maka dapat dipahami dalam kajian ini far'unya adalah zakat profesi.

Ketiga, 'illat (ratio legis). Yaitu sebab yang menyambungkan pokok (al ashlu) dengan cabangnya, atau dapat dipahami, 'illat ialah; sifat yang berpengaruh terhadap hukum, bukan karena dzatnya, melainkan atas perbuatan syari'. Dalam konteks ini, illat dari zakat profesi diwajibkan bagi umat Islam, karena berkembang (al nama'), hal ini sama dengan illat atas diwajibkannya objek zakat lainnya yang disebutkan dalam fiqh klasik konvensional.

Keempat, al hukmu (hukum). Yaitu suatu hukum tertentu yang melekat pada al ashlu/maqis 'alayh, yang merupakan sandaran hukum dalam aktifitas penggunaan qiyas. Maka dapat difahami, hukum muncul dalam kajian ini adalah kewajiban atas terlaksannya zakat emas dan perak bagi setiap Muslim sesuai dengan syarat dan ketentuan yang berlaku. Yang pada akhirnya, hukum yang berlaku pada emas dan perak ini juga berlaku pada hukum wajibanya zakat profesi untuk ditunaikan bagi setiap umat Islam.

2. Keniscayaan pengembangan objek zakat

Hingga saat ini, asumsi bahwa zakat adalah `ibadah maliyah yang bersifat tawqifi masih kuat mencengkram sebagian besar masyarakat Indonesia. Asumsi ini mengandaikan bahwa perintah zakat harus dijalankan sesuai dengan teks hadits yang berhubungan dengan harta-harta yang wajib dizakati tanpa ada 'illat. Tentu saja, asumsi demikian perlu dikoreksi secara mendalam sebab pada kenyataannya saat ini telah banyak kelompok yang berpenghasilan besar lewat profesi tertentu yang tidak termasuk dalam kategori wajib-zakat (muzakki) sebagaimana tercantum dalam fiqh klasik. Padahal, penghasilan mereka jika dibandingkan dengan kategori muzakki dalam fiqh klasik sebenarnya memenuhi syarat untuk dikeluarkan zakatnya. 
Misalnya, seorang dokter, anggota legislatif, dan beragam jenis profesi lainnya. Dalam fiqh klasik, profesi seperti itu sama sekali tidak disentuh sebagai bagian dari harta dan penghasilan yang menjadi sasaran objek zakat, maka dari itu pemahaman yang lahir, seakan-akan mereka bukanlah kelompok yang diwajibkan membayar zakat. Mereka bukanlah peternak hewan, pedagang, penambang, dan bukan pula petani. Penghasilan mereka tidaklah dalam bentuk emas dan perak. Karena itu, bila mengacu pada kategorisasi muzakki yang disodorkan fiqh klasik jelas mereka tidak termasuk di dalamnya. Padahal, tidak tertutup kemungkinan penghasilan mereka jauh lebih besar ketimbang penghasilan para petani, pedagang, penambang, dan peternak hewan yang jika telah mencapai nisab diwajibkan mengeluarkan zakat.

Maka akan sangat ironis dan terkesan menjauhi prinsip keadilan dan keberpihakan Islam kepada kaum miskin (dhu'afa) apabila kelompok yang berpenghasilan tertentu (dalam konteks ini petani, peternak hewan, penambang, dan pedagang) diwajibkan mengeluarkan zakat dengan alasan telah dibahas tuntas oleh fiqh klasik. Sementara itu, kelompok lain yang berpenghasilan jauh lebih besar tidak dituntut kewajiban membayar zakat gara-gara profesi mereka tidak ditemukan dalam pembahasan fiqh klasik.

Penting untuk disadari, prinsip yang dikembangkan dalam aktualisasi konsep zakat adalah prinsip aktualisasi pemetaan obyek zakat tergantung pada karakteristik barang apakah dapat tumbuh dan berkembang atau tidak. Sehingga objek zakat tidak hanya terpaku pada apa yang telah disabdakan oleh Nabi Muhammad, melainkan berkembang dan selalu sejalan dengan arus peradaban dan ekonomi masyarakat.

Sebagai respon atas hal ini, beberapa ulama' fiqh kontemporer seperti al Qardawi terdorong untuk menganalisis fenomena ini. Akhirnya, mereka sampai pada kesimpulan hukum (fatwa) untuk memberlakukan satu jenis zakat yang kemudian populer dengan istilah zakat profesi.

\section{Simpulan}

Dari paparan yang sudah dijelaskan diatas, dapat disimpulkan bahwa; metode yang digunakan oleh Yusuf al Qardawi dalam beristinbath untuk menentukan dasar wajibnya zakat profesi bagi setiap umat Islam adalah metode qiyas, dengan ketentuan: maqis 'alayhnya adalah zakat emas dan perak; 'illatnya adalah berkembang ( $a$ l nama'); hukumnya adanya kewajiban zakat bagi profesi yang senilai dengan emas-perak atau seperti diwajibkannya zakat emas-perak; dan far'unya zakat profesi. 
Sedangkan implikasi yang muncul dari hasil metode istinbath seperti yang disebutkan diatas bagi pengembangan objek zakat di Indonesia adalah, bahwa objek zakat di Indonesia yang pada mulanya hanya bertumpu pada objek zakat yang didasarkan fiqh klasik konvensional (zakat emas-perak, perdagangan, pertanian-tanaman, hewan dll), menuju ke arah objek zakat pada bidang pekerjaan-pekerjaan serta profesi yang tumbuh dan berkembang di era modern, seperti komisaris perusahaan, advocat, akuntan publik, serta bidang-bidang pekerjaan yang mengedepankan industri kreatif.

\section{Daftar Pustaka}

Abdurrahman, Asymuni. 1986. Metode Penetapan Hukum Islam. Jakarta: Bulan Bintang.

Al Amid. 1991. Al Ihkam fi Ushul al Ahkam. Kairo: Matba'ah al Ma'arif.

Al Bigha, Musthafa Zib. 1989. Al Tazhib fi Adillati Matni al Ghayati wa al Taqrib (cetakan IV). Bairut: Dar Ibnu Kasir.

Dewan Redaksi. 2005. Ensiklopedi Islam (jilid V). Jakarta: PT Ichtiar Baru Van Hoeve.

Dahlan, Abdul Aziz (et.al.). 1996. Ensiklopedia Hukum Islam. Jakarta: Ichtiar Baru Van Hoeve.

Fachruddin HS. 1992. Ensiklopedia al Quran (cetakan I). Jakarta: Rineka Cipta.

Faridah. "Persepsi Kyai Pondok Pesantren Terhadap Zakat Profesi”. Jurisdictie. Volume 2 Nomor 1 Juni 2011.

Al Ghazali. 1937. Al Mushtasfa. Kairo: Mathba'ah Mustafa Muhammad.

Hasbullah, 'Ali. 1964. Ushul al Tasyri' al Islami. Mesir: Dar al Ma'rifah.

Hariyanto, Beni. 2006. Analisis Pemikiraan Didin Hafiduddin tentang Zakat Profesi. (skripsi). Semarang: Fakultas Syari'ah Institut Agama Islam Negeri (IAIN) Walisongo Semarang.

Hafidhuddin, Didin. 2004. Panduan Praktis Tentang Zakat Infak Sedekah (cetakan IV) Jakarta: Gema Insani Press.

Isma'il, Syauqi. 1986. Penerapan Zakat di Dunia Modern. Jakarta: Pustaka Dian 
Antar Kota.

Djamil. Fathurrahman. 1997. Filsafat Hukum Islam. Jakarta: Logos Wacana Ilmu.

Junaidi, Ahmad. 2004. Jurnal al Banjari. Nomor 6 Volume 3.

Aripin, Jaenal. 2012. Kamus Ushul Fikh. Jakarta: Kencana.

Kurde, Nukthoh Arfawie. 2005. Memungut Zakat dan Infaq Profesi oleh Pemerintah Daerah bagi Pegawai Negeri dan Pegawai Perusahaan Daerah (cetakan I). Yogyakarta: Pustaka Pelajar.

Kohar, Mas'ud Khasan Abdul. 1988. Kamus Istilah Ilmu Pengetahuan. Surabya: Usaha Nasional.

Khin, Mustafa Sa'id. 1998. Asrar al Ikhtilaf fi al Qawa’id al Ushuliyyah fi Ikhtilafi al Fuqaha'. Bairut: al Risalah.

Khallaf, Abdul Wahhab. 1996. Kaidah-Kaidah Hukum Islam. Terjemahan oleh Noer Iskandar al Basrany. Jakarta: Raja Grafindo Persada.

Khallaf, Abdul Wahhab. 1942. 'Ilmu Ushul al Fiqh. Kairo: Maktabah ad Da'wah alIslamiyyah.

Khallaf, Abdul Wahhab. 1972. Masadir al Tasyrie' al Islami fi ma La Nassha. Kuwait, Dar al Qolam.

Latifah, Faridatul. 2010. Zakat Profesi Perspektif al Qardawi dan Didin Hafiduddin, Skripsi Fakultas Syari'ah UIN Sunan Kalijaga Yogyakarta.

Muhammad. 2002. Zakat Profesi: Wacana Pemikiran dalam Fiqh Kontemporer (cetakan I). Jakarta: Salemba Diniyah.

Kelib, Abdullah. 1996. Hukum Zakat Profesi Dan Pelaksanaannya Pada Kalangan Profesional Muslim di Kota Madya Semarang. Semarang: Universitas Islam Sultan Agung.

Mahfud, Sahal. 1994. Nuansa Fiqh Sosial. Yogayakarta: LKiS bekerjasama dengan Pustaka Pelajar.

Al Mawardi. t.th. al Hawi al Kabir. Juz III. Bairut: Dar al Kitab al 'Ilmiyyah.

Al Na'im, Abdullah Ahmad. 1990. Dekontruksi Syari'ah. Terjemahan oleh 
Ahmad Suaedi (cetakan I). Yogyakarta: LKiS.

Praja, Juhaya S. 1995. Filsafat Hukum Islam. Bandung: UNISBA.

Qadir, Abdurrahman. 1990. Studi Pembaharuan Hukum Islam, Studi Pemikiran Yusuf al Qardawi tentang Zakat Profesi. Jakarta: IAIN Syarif Hidayatullah.

Al Qardawi, Yusuf. 1973. Figh al Zakah Dirasah Muqaranah li Ahkamiha wa Falsafatiha fi Dhaw'i al Quranwa al Sunnah ( cetakan III). Bairut: Muassasah al Risalah.

Al Qardawi, Yusuf. 2003. Perjalanan Hidupku 1. Terjemahan oleh Cecep Taufikurrahman dan Nandang Burhanuddin. Jakarta: Pustaka al Kautsar.

Al Qardawi, Yusuf. 1994. Masalah-Masalah Islam Kontemporer, alih bahasa Muhammad Ichsan (cetakan I). Jakarta: Najah Press.

Al Qardawi, Yusuf. 1996. Fiqh al Zakah (Hukum Zakat) Terjemahan oleh Didin Hafidhuddin, Salman Harun dan Hasanuddin (cetakan IV). Bogor: Pustaka Litera Antar Nusa.

Shihab, M. Quraish. 1999. Membumikan al Quran. Bandung: Mizan.

Sabiq, Sayid. 1983. Fiqh al Sunnah (jilid I, cetakan IV). Bairut: Darul Fikr.

Al Syawkani. tt. Naylu al Awtar (jilid IV). Bairut: Daru al Jail.

Al Shiddieqy, T.M. Hasbi. 1984. Pedoman Zakat. Jakarta: PT. Bulan Bintang.

Salim, Peter Salim dan Yenny. 1999. Kamus Bahasa Indonesia Kontemporer. Jakarta: Modern English Press.

Al Sarakhsi. 1954. Ushul al Sarakhsi. Kairo: Matba'ah Dar al Kitab al 'Arabi.

Tim Lajnah Ta'lif wan Nasyr (LTN) PBNU. 2011. Ahkamul Fuqaha: Solusi Problematika Aktual Hukum Islam, Keputusan Mukatamar, Munas, dan Konbes Nahdlatul Ulama' (1926-2010 M). Surabaya: Khalista.

Tim Penyusun. 1988. Kamus Pusat Pembinaan dan Pengembangan Bahasa. Kamus Besar Bahasa Indonesia. Jakarta: Depdikbud, Balai Pustaka.

Usman, Muchlis. 2002. Kaidah-Kaidah Ushuliyah dan Fiqhiyah. Jakarta: PT. 
Raja Grafindo Persada.

Yasid, Abu. 2012. Metodologi Penafsiran Teks, Memahami Ushul Fiqh Sebagai Epistemologi Hukum. Jakarta: Penerbit Erlangga.

Al Zuhaili, Wahbah. Tt. Al Wajiz Fi Ushuli al Fiqh. Bayrut: Dar al Fikr.

Zuhdi, Masjfuk. 1997. Masail Fighiyah (cetakan X). Jakarta: Gunung Agung.

Zein, Satria Efendi M. 2005. Ushul Fiqh. Jakarta: Prenada Media. 